„Analiza i Egzystencja” 34 (2016)

ISSN 1734-9923

DOI: 10.18276/aie.2016.34-05

ARTYKUŁY

\title{
KATARZYNA SZKARADNIK*
}

\section{CZŁOWIEK W IMPERIUM CZASU, SENS W IMPERIUM ZNAKÓW. HERMENEUTYKA A TEKST HISTORII*}

Słowa kluczowe: hermeneutyka, sens historii, narratywizm, tradycja, tekst historii, dziejowość

Keywords: hermeneutics, the sense of history, narrativism, tradition, the text of history, histioricity

* Katarzyna Szkaradnik - absolwentka filologii polskiej i kulturoznawstwa, doktorantka na Wydziale Filologicznym Uniwersytetu Śląskiego w Katowicach. Publikowała m.in. w czasopismach „Hybris”, „Anthropos?”, „FA-art”, „Kultura i Historia”. Recenzentka w dwutygodniku kulturalnym ,,artPAPIER”, współredaktorka Dzienników z lat 1935-1945 Jana Szczepańskiego, uhonorowanych Nagrodą Historyczną „Polityki” w 2010 r. Do jej zainteresowań należą m.in. antropologia literatury, problematyka tożsamości, historia idei, filozofia hermeneutyczna i egzystencjalna. E-mail: kasiorek1987 @tlen.pl.

Address for correspondence: E-mail: kasiorek1987@tlen.pl.

** Artykuł powstał w ramach projektu finansowanego ze środków Narodowego Centrum Nauki przyznanych na podstawie decyzji nr DEC-2012/07/N/HS2/00966. 


\section{Wprowadzenie, czyli o zasadzkach narracji}

Pogłębienie namysłu nad rolą medium językowego w różnych dziedzinach nauki ${ }^{1}$ - od etapu definiowania przedmiotu badań, przez ich przebieg i określenie wyniku, po prezentację wniosków - przyniosło przełom również w teorii historiografii. Ową reorientację uważa się zazwyczaj za pokłosie tzw. linguistic turn (por. Rorty, 1967), aczkolwiek wychodzące z podobnych przesłanek krytyczne podejście do pracy dziejopisów można znaleźć już choćby u Nietzschego. Krótko mówiąc, chodzi o odsłonięcie nieprzezroczystości dyskursu historycznego, zakwestionowanie jego pretensji do bezstronności i do odkrywania ,jak było naprawdę", skoro prawda stanowi raczej historyczny - a więc zmienny - konstrukt, ,ruchomą armię metafor, metonimii i antropomorfizmów" (Nietzsche, 1993, s. 189).

O ile gros historyków nadal zapatruje się na tego rodzaju tezy sceptycznie, broniąc tradycyjnie pojętej naukowości dyscypliny, o tyle można chyba zaryzykować twierdzenie, że literaturoznawcy dość zgodnie zaaprobowali uznanie tekstowego aspektu historii za doniosły, lub nawet prymarny. W takim ujęciu historia jawi się jako sui generis opowieść, tj. poniekąd jako materiał do analiz literaturoznawczych ${ }^{2}$. Za sprawą zwrotu lingwistycznego, szczególnie zaś narratywistycznego (por. np. Domańska, 2012, s. 25-47), wyeksponowane zostały fabularność dzieła historiograficznego oraz jego struktura retoryczna, odsyłająca zarówno do reguł kompozycyjnych i tropów danego języka, jak i do niewyartykułowanych przekonań dziejopisa. Niemniej, jeśli oparte na takich założeniach rozbiory zamieszczone w Metahistory (1973) Haydena White'a sprawiają wrażenie typologii stylów historiograficznych na modłę strukturalizmu (por. Domańska, 2010, s. 12-15), to obecnie w teoriach badań nad przeszłością dominuje inspirowany przez antropologię kulturową zwrot m.in. ku rzeczom i afektom (por. np.

1 W interesującym mnie kontekście hermeneutyki por. np.: „Myślenie o języku nie jest nigdy w stanie wyprzedzić języka. [...] We wszelkiej naszej wiedzy o nas samych i o świecie jesteśmy już raczej ogarnięci [...] przez nasz własny język" (Gadamer, 1979b, s. 50).

2 Warto przywołać tu np. nurt zwany nowym historyzmem, por.: „Historyczność tekstów i tekstualność historii: jeśli takie chiazmatyczne sformułowania są teraz w modzie, [...] to może jest tak dlatego, że tworzą one z wnętrza samego dyskursu model dynamicznych [...] relacji między sferą dyskursywną a materialną" (Montrose, 1996, s. 132). 
Budrewicz, Sendyka, Nycz, 2014; Olsen, 2013), a wraz z nimi ku kategorii pamięci. Wymienione sfery winny bardziej adekwatnie niż generalizujący ogląd historyka oddawać czy (re)konstruować doświadczenie jednostki, którego nie sposób wypreparować z cielesności i które niekiedy - tak jak makabra Holocaustu - oscyluje na granicy możliwości wysłowienia.

\section{Sens pytania o sens}

Gwoli jasności wypada przywołać elementarne rozróżnienie terminologiczne między dziejami jako ciągiem zdarzeń w świecie ludzkim (res gestae) a historią jako narracyjnym przekazem wiedzy o przeszłości zgodnej z ustaleniami badaczy (rerum gestarum). Prócz tego pod pojęciem historii rozumie się opowieść o pewnym zdarzeniu albo coś reprezentującego przeszłość. Jeśli abstrahujemy od dziejów, w których tu i teraz uczestniczymy, to z innymi ich wycinkami obcujemy jako z historią - przekazami materialnymi bądź werbalnymi, przy czym te pierwsze także są już oplecione siatką opisów $\mathrm{i}$ interpretacji. Czy jednak dostrzegając $\mathrm{w}$ historii zasadniczo przekaz-tekst (lub raczej nieskończoną wielość tekstów), decydujemy się eo ipso na demaskowanie jego wzorców stylistycznych i uwikłań ideologicznych, do czego skłania akceptacja założeń konstruktywizmu? Czy na gruncie tekstowego rozumienia historii można doszukiwać się w niej miejsca dla ludzkiej (po)szczególności, a tym bardziej - dla sensu? Ten ostatni wydaje się przecież nieodwołalnie być na usługach władzy jako narzędzie jej legitymizacji, w dodatku chęć przypisania sensu procesowi historycznemu budzi skojarzenia z wiarą w rzekomą konieczność dziejową, historię uniwersalną i cele ostateczne. Obronę przed takim unifikującym „monomitem” Odo Marquard (wyraziciel dość powszechnej opinii, ale związany z kluczową tutaj hermeneutyką) upatruje w naukach humanistycznych, które - dzięki opowiadaniu równorzędnych i wielorako interpretowalnych historii (Geschichten) - naruszają hegemonię wizji jednotorowego biegu dziejów (por. Marquard, 2001, s. 109).

Niemniej, o ile zgubne konsekwencje utopijnych „metanarracji” każą przedstawicielom współczesnej myśli zachodniej najczęściej traktować kategorię sensu podejrzliwie, o tyle mnogość mikrohistorii heterogenicznych grup, spośród których można by wybierać niczym na wolnym rynku (por. np. Bauman, 2009, s. 119-123), wydaje się skorelowana z deficytem „mocnego” 
ontologicznie sensu. Sensu, czyli tego, dzięki czemu coś - w tym wypadku ludzka egzystencja w ,imperium czasu” - staje się zrozumiałe, zdatne do zaakceptowania i/lub godne realizacji (por. Hartman, 2004, s. 203). Nie mamy tu do czynienia wyłącznie $z$ obawą konserwatystów i duchownych, negujących nowoczesne przemiany obyczajów, lecz z diagnozą myślicieli i badaczy o różnych orientacjach, którzy konstatują trudności ze wskazaniem punktu odniesienia dla trajektorii jednostkowego losu, potęgowane napięciem między indywidualizacją a globalizacją stylów życia. Krach stabilnych ram tożsamości - narracji podsuwających na nią ,pprzepis” - przeistacza członków tzw. społeczeństw ponowoczesnych w poszukiwaczy sensu pośród metakultury nowości (por. Burszta, Kuligowski, 2005, s. 226).

Rzecz jasna, w nakreślonej tutaj optyce „sens” jest być może rozumiany nazbyt emfatycznie, przed czym przestrzega Marquard (1994b, s. 40), zauważając, że problem bierze się z maksymalizmu, tzn. wygórowanego żądania sensu. Owszem, oczekiwanie na jego bezpośrednie „objawienie się" umniejsza wartość codziennej krzątaniny (por. rozdział Krzątactwo w: Brach-Czaina, 1999, s. 55-80), a wiara w tzw. inny świat - prawdziwszy, gdyż sensowny sam z siebie ${ }^{3}$ - nadaje ,temu światu” status sensownego zaledwie akcydentalnie, pochodnie. Dla kultury zachodniej prototypem owej par excellence sensownej rzeczywistości stały się chrześcijańskie zaświaty, przeto zgodnie z argumentacją Karla Löwitha (2002) również nowoczesną teleologiczną filozofię dziejów należałoby rozpatrywać jako ich zeświecczoną teologię. Wszakże tacy współcześni myśliciele hermeneutyczni jak John Caputo czy Gianni Vattimo podkreślają (wraz z szeregiem innych teoretyków), że właśnie na skutek podważenia prowidencjalizmu utraciło sens odwoływanie się do historii, aby umotywować zbiorowe losy (por. Vattimo, 1998, s. 131), jednostka zaś staje w obliczu ,permanentnego załamywania się znaczeń i sensu" (Leśniewski, 1998, s. 161).

Taki sąd brzmi intrygująco, ponieważ kwestia sensu jawi się jako absolutnie centralna dla hermeneutyki. Kontrastując tę orientację z nurtami (post)strukturalistycznymi, Paweł Dybel (2012, s. 44) zwraca uwagę, że sens nie podlega zredukowaniu do signifié, które da się wyznaczyć po

3 Por.: „[...] przypuśćmy, że nie ma innego świata, świata metafizycznego, i że wszelkie objaśnienia świata jedynie nam znanego zaczerpnięte z metafizyki są dla nas do niczego; jakim wzrokiem patrzylibyśmy wtedy na ludzi i rzeczy?" (Nietzsche, 1908, s. 39-40). 
rozpoznaniu signifiants powołujących je do istnienia (co zachodzi nawet wówczas, gdy owe „znaczące”, jak wykazuje dekonstrukcja, multiplikują się). Sens bywa mianowicie napotykany jako fenomen samoistny o pewnym residuum tożsamości (czyli rozpoznawalnej swoistości), a zarazem jako pytanie, wyzwanie, coś żywo dotykającego, poruszającego. Przewrotnie można by stwierdzić, że wobec tego najsensowniejszymi trzeba nazwać nie tylko toczące się wokół nas i z nami dzieje, w które jesteśmy zaangażowani od urodzenia, lecz również absurdalne cierpienie niewinnych ofiar - ono przecież najbardziej daje do myślenia. Tymczasem często ono właśnie stanowi ostateczny argument za niemożnością usprawiedliwienia biegu dziejów, co z kolei pociąga za sobą brak uzasadnień dla niezbywalnego znaczenia każdego indywiduum w rzeczonym procesie.

Chciałabym jednak zastanowić się, czy na pytanie o sens historii nie warto spojrzeć pod innym kątem, skłaniam się bowiem ku stanowisku, że linguistic turn i płynące z niego tezy otwarły hermeneutyczne pole do odzyskiwania wspomnianego wyżej podmiotowego sensu. Spróbuję zatem przez pryzmat hermeneutyki rozważyć, czy w namyśle nad historią można wydostać się poza ,imperium znaków” tak, aby nie było to wyjście ku Heideggerowsko pojmowanej nicości. Wszak nawet propagujący „osłabienie” roszczeń metafizyki Vattimo (1998) zastrzega: „Uznanie końca »metaopowieści« nie oznacza, jak w reaktywnym i mściwym nihilizmie opisanym przez Nietzschego, że pozostaje się bez żadnego kryterium wyboru, bez żadnej nici przewodniej" (s. 144).

\section{Wobec głosów z przeszłości}

Paradoks zdeterminowania i (do)wolności w odniesieniu do dziejów i historii można zobrazować w obrębie klasycznej myśli hermeneutycznej stwierdzeniem Paula Ricoeura (2008, s. 321-322), że nim jeszcze człowiek zacznie zadawać przeszłości pytania i zgłaszać wobec niej wątpliwości - ona czyni to z nim samym. Pojawiająca się w tym zdaniu hipostaza nabiera konkretnej treści, kiedy w charakterystyce owej przeszłości uwzględni się fundamentalne rozpoznanie Hansa-Georga Gadamera (2007, s. 381), że nie tyle dzieje należą do nas, ile my - ich wytwór - należymy do nich. Dzieje przenikają nasze myślenie, rzutując na specyfikę rozumienia, nieusuwalnie zmediatyzowanego i usytuowanego. Marquard (1994a, s. 81) mówi tutaj o „rodowodzie”, 
czyli tym, co człowiek poznaje jako datum i czym nie rozporządza, a także tym, czym już definitywnie się stał. Z powodu bezustannego przybywania zdarzeń usytuowanie jest jednak poddane translokacjom, rodowód zaś okazuje się ruchem stawania się, ciągłej aktualizacji. Z jednej strony zatem „dowolność" wyboru historii sprawia wrażenie problematycznej, z drugiej natomiast $-\mathrm{z}$ określonego punktu $\mathrm{w}$ dziejach historię każdorazowo ujmuje się inaczej. Jak zaznacza Gadamer (2003):

[...] ideał obiektywności badań historycznych stanowi [...] drugorzędną stronę problemu, albowiem wyodrębnienie samego doświadczenia historycznego sprawia, że tkwimy wewnątrz pewnego dziania się, nie wiedząc, co nam się przytrafia, a to, co się wydarzyło, chwytamy dopiero, patrząc wstecz. Zgodnie z tym każda teraźniejszość musi napisać historię na nowo (s. 102).

W przytoczonym wywodzie słychać echa Heglowskiej idei ,wylatującej o zmierzchu sowy Minerwy", ale nie chodzi w nim przecież o banalne spostrzeżenie ilościowego przyrostu dzieł historyków i weryfikowania wiedzy na temat wydarzeń w świetle odkrywanych dokumentów. Sednem wydaje się konstatacja naszej niezdolności do przyjęcia postawy zewnętrznego, chłodnego obserwatora - dotyczy to tyleż dziejów, co historii, czyli przekazów o nich, które można identyfikować z tradycją. Ponieważ przeciw Gadamerowi (również ze strony hermeneutyki radykalnej) padają oskarżenia o apologię tradycji (por. Caputo, 2000, s. 41-55) ${ }^{4}$, warto powtórzyć, że jednostka ludzka „wrzucona-w-świat” (usytuowana) jest wrzucona w płynną konfigurację bieżących okoliczności (w liczbie mnogiej). Warto też zauważyć, że nie wyrasta ona z jakiejś jednej tradycji, lecz z wielu, jeśli za Ricoeurem (2008, s. 320) definiować tradycje jako rzeczy już powiedziane, przekazywane w łańcuchu interpretacji i reinterpretacji ${ }^{5}$. Z punktu

4 Wydaje się jednak, że tradycja w rozumieniu Gadamera odległa jest od tej będącej przedmiotem krytyki Heideggera (1994): „Przejmująca władanie tradycja czyni [...] to, co »przekazuje«, tak bardzo niedostępnym, że wręcz to zakrywa. [...] W rezultacie jestestwo, przy całym swym zainteresowaniu historią $[\ldots]$, przestaje rozumieć [...] elementarne warunki umożliwiające pozytywny zwrot ku przeszłości w sensie produktywnego przyswojenia jej sobie" (s. 30-31).

5 Vattimo (2011) jeszcze „osłabia” owo pojęcie, wskazując, że tradycja,,jest nie tylko prawdą biblioteki Babel rozumianą jako niemożliwa do zredukowania polifoniczność, [...] [ale również] bycie jawi się tu jako rozbita obecność" (s. 107). 
widzenia socjologii można by rzec, że przynależymy do rozmaitych grup, z których wszystkie mają swoje tradycje - historię przykładowych realizacji (wcieleń) danej tożsamości i ich ocen. Ktoś może być chociażby Polakiem, protestantem, Ślązakiem, chłopem, bibliofilem, hutnikiem, socjalistą, pisarzem, ludowcem itd. ${ }^{6}$, aczkolwiek wymienione role nieraz wchodzą ze sobą w kolizję. Każda istotna decyzja człowieka zależy od tradycyjnych znaczeń i wartości przypisanych danym tożsamościom, niemniej - podlegając trzem wymiarom czasowości - jest on formowany zarówno przez ciągłość, jak i modyfikacje znaczeń: te już zastane (włączone w tradycję) oraz własne.

Tradycje $\mathrm{w}$ takim razie stanowiłyby pewne propozycje sensu sytuujące się w porządku możliwej prawdy (por. Ricoeur, 2008, s. 323), której nie należy postrzegać jako transcendentnej i obiektywnej instancji, lecz która właśnie w dziejach się wyłania. Z tej wydarzeniowej perspektywy tradycja nie przypomina zniewalającego schematu myślenia, ale okazuje się obszarem potencjalnych wyborów i argumentów, a więc formalnym horyzontem przemian i wolności (por. Feliksiak, 2014, s. 29). Powtarzalność niektórych wyborów i długie trwanie wartości - co oddaje ,zasada dziejów efektywnych" (Wirkungsgeschichte), akcentowana przez Gadamera (2007, s. 412-421) - opiera się tutaj na podmiotowym świadectwie, czyli każdorazowym potwierdzaniu owych wartości w życiu. Potwierdzaniu poprzedzonym aktualizującą interpretacją mnogości głosów, które dobiegają z głębi dziejów.

Głosy te docierają do nas głównie w postaci zapisów, przeto w ich analizie nie należy postponować wymiaru językowego, a nawet literackiego, jest on bowiem czymś więcej niż naddatkiem. Jak powiada Ricoeur (2008):

częściowa równoważność zachodząca między hermeneutyką tekstową a hermeneutyką historycznej przeszłości znajduje wsparcie w tym, że historiografia - jako wiedza zdobywana poprzez ślady - w dużym stopniu zależy od tekstów, które nadają przeszłości status dokumentu. $\mathrm{W}$ ten sposób rozumienie tekstów odziedziczonych z przeszłości może zostać podniesione [...] do rangi doświadczenia będącego świadectwem względem każdego odniesienia do przeszłości. Literacki aspekt tego dziedzictwa [...] równa się wycięciu „okna” dającego widok na ogromny pejzaż przeszłościowości jako takiej (s. 321).

6 Pierwowzorem tego „kogoś” jest wuj przywoływanego w dalszej części szkicu socjologa Jana Szczepańskiego (por. jego szkic Przykład Jana Wantuły, 1973). 
Godne podkreślenia jest tu, po pierwsze, przenikanie się przekazów historycznych $\mathrm{z}$ aktualnym byciem jednostki, zawarte $\mathrm{w}$ kategorii świadectwa. Po drugie, podobnie jak dzieło literackie otwiera przed czytelnikiem nowe światy tudzież poszerzone możliwości istnienia (por. Ricoeur, 1989, s. 287), tak w historiografii medium języka pozwala na głębsze uczestnictwo w dziejach i łączność z przeszłością, do której nie ma bezpośredniego dostępu; dzięki temu metafora „rozmowy z przeszłością” nie wydaje się nadużyciem. Trzeba wszakże pamiętać, że autor Czasu i opowieści (2008) uwypukla uprzedniość pytania stawianego przez przeszłość, a zarazem - obustronną aktywność w toku owej specyficznej komunikacji: „W tej walce o rozpoznanie sensu tekst i czytelnik kolejno się do siebie zbliżają i od siebie oddalają" (s. 321-322) 7 . Zacytowane słowa dotyczą historiografii, nie fikcji, podczas gdy zdaniem Hansa Roberta Jaussa (1999, s. 204) w „,otwartej relacji sensu, pytania i odpowiedzi” zapośredniczone historycznie pytanie pojawia się dopiero, kiedy tekst z przeszłości zdaje się podsuwać żywotną odpowiedź w dokonanej przez nas współcześnie konkretyzacji - i tym różni się dzieło literackie od zapisów będących wyłącznie ,świadectwami epoki”. Niemniej w obydwu wypadkach odniesienie do ludzkiego bycia sugeruje, że pojęcie sensu nie oznacza nieistotnego egzystencjalnie „rozszyfrowania” treści wypowiedzi pisemnej. Ponadto obaj autorzy, mówiąc o „rozpoznaniu” i ,podsuwaniu”, wyrażają przeświadczenie, że sens sygnalizowany jest przez przekaz, ale jego przyswojenie następuje w dynamicznej konfrontacji. Można tę ambiwalencję rozumieć jako obronę przed zarzutem imputowania odbiorcy gotowej, ,jedynie poprawnej” interpretacji, równocześnie zaś jako uwydatnienie faktu, że wchodząc w świat języka (ergo przekazów z przeszłości), człowiek nieodłącznie wchodzi w świat możliwych oraz już zrealizowanych sensów (sposobów bycia).

\section{Sens historii historyków}

Należy jednak wziąć poprawkę na okoliczność, że czytelnik doszukujący się sensu w przekazach nieliterackich - ,świadectwach epoki" - korzysta przeważnie z pośrednictwa systematyzującego je historyka. W tym kontekście

\footnotetext{
Wszystkie podkreślenia kursywą pochodzą od autora cytowanego tekstu, pogrubienia - od autorki artykułu.
} 
trafne i ważne zdają się obserwacje Jana Szczepańskiego, który o funkcjach dziejopisów pisze z pozycji socjologa, ale także zmaga się z czasem w swojej twórczości eseistycznej i diarystycznej. W książce Historia mistrzynia życia? przekonuje:

Taka całość jest konstruowana przez historyka zgodnie z jej immanentnym sensem, który historyk albo wyczuwa i mu się poddaje, albo odkrywa w szczegółowych analizach poszczególnych grup zdarzeń. [...] z takiej sensownej konstrukcji czy syntezy historycznej inteligentny i filozoficznie wrażliwy czytelnik może odczytać, na czym polegał sens życia poszczególnych ludzi w tej epoce. [...] historyk odpowiada [więc] także na pytania: po co żyli ludzie w tej epoce? Do czego dążyli? [...] Jaki nadawali swojemu życiu subiektywny sens? A jeżeli historyk nie stawia sobie wprost zadania, by odpowiadać na takie pytania, wtedy [...] odpowiada na nie niejako w uwikłaniu. I czytelnik jego dzieła wydedukuje je ze sposobu opisywania zachowań ludzi (Szczepański, 1990, s. 225-226).

Zarówno (re)konstrukcja, jak i recepcja sensów przypisywanych (nadawanych) egzystencji poprzednich pokoleń następują zatem mniej lub bardziej intencjonalnie, wnikliwie i otwarcie. Wzmiankowane uwikłanie historyka oznaczałoby, z jednej strony, konstelację niewyrażonych jawnie przekonań, z drugiej, spuściznę tego, co już o danym wycinku dziejów napisano. W chwili, gdy ów badacz czy popularyzator przystępuje do pracy, włącza się w dwojaką dialektykę. Po pierwsze, człowiek będący „,produktem” dziejów wytwarza historię, której interpretacja nie pozostaje bez wpływu na dalsze ludzkie działania, kształtujące z kolei dzieje. Po wtóre, dialektyka rozgrywa się między wektorami czasu, gdyż to, co Ricoeur (2008, s. 301) za Reinhartem Koselleckiem zwie horyzontem oczekiwania, dotyczy również spraw przeszłych - dziejopis projektuje wszak historyczny horyzont. Nie może jednak postępować całkiem arbitralnie, ponieważ natrafia na aktywność przeszłości i podlega jej oddziaływaniu:

[...] praca historii oraz praca historyka wzajemnie się wspierają. [...] czasowy dystans oddzielający nas od przeszłości jest nie martwą przestrzenią, lecz twórczym przekazem sensu. Zanim stanie się bezwładnym osadem, tradycja jest działaniem, które może być pojęte jedynie dialektycznie w wymianie zachodzącej między interpretowaną przeszłością a interpretującą teraźniejszością (tamże, s. 320). 
Autor Pamięci, historii, zapomnienia potwierdza zatem wskazane już w niniejszym szkicu rozpoznanie tradycji jako sfery niezastygłego sensu, aktywowanego przez wcielanie go we własne życie. Niemniej pozostaje kwestia pewnej instrumentalizacji, jaką niesie ze sobą ,horyzont oczekiwań”. Po pierwsze, oczekiwań odbiorców historii, dla których interpretacje przeszłości są czymś, co służy próbom - nie zawsze świadomym - uporania się z własną skończonością (por. Gadamer, 1979c, s. 24-25). Jak zauważa Szczepański (1990, s. 103-104), potoczne filozofie dziejów budowane na potrzeby codzienności przez tzw. zwyczajnych ludzi dostarczają sił do radzenia sobie z przemijaniem oraz wiary w to, że życie w swojej znikomości, niedoskonałości, a nierzadko trywialności stanowi przęsło procesu dziejowego, którego sens ujawnią kiedyś historycy - lecz nie studiujący dokumenty archiwiści, ale ci zdolni do wykreowania „wizji porywającej pokolenia".

$\mathrm{Z}$ diagnozy tej wyłania się trwała inklinacja człowieka do hołdowania totalizującym ,metanarracjom”, fundamentalizmom, które nadają godność i wzniosłość jego egzystencji przez doniosły sens zbiorowej „tradycji wynalezionej". W obliczu takiego zagrożenia rację zdaje się mieć Marquard z postulatem ,dietetyki oczekiwania na sens”, a ze stanowiska hermeneutyki radykalnej - Vattimo i Caputo zalecający zerwanie z oszukiwaniem się oraz przyzwolenie na „brak gruntu” i ,upływ” bycia ${ }^{8}$, czyli (mimo „osłabiania” przez obydwu metafizycznego patosu) pewien heroizm w obliczu skończoności. Kłopot w tym, że to drugie wezwanie de facto skierowane jest raczej do jednostek o profilu duchowym nadczłowieka lub Kierkegaardowskiego „rycerza wiary” $i$ trudne do zastosowania w powszedniej praktyce większości ludzi. Tymczasem, jak poucza Szczepański (1990):

Pytanie o [...] sens własnego działania [...] w takiej czy innej postaci stawia sobie każdy człowiek. A jeżeli nie może się doszukać sensu w zakresie swoich spraw, wtedy zwraca się do historii, by z niej odczytać wykrystalizowany już sens procesu. Historyk bowiem [...] musi przyjąć jakieś założenia ontologiczne dotyczące natury bytu społecznego, który bada. [Szuka on] [...] wewnętrznej spójności i sensowności łańcucha zdarzeń, gdyż nie może przyjąć, że dzieje są po prostu chaosem przypadków, bez jakiegoś wątku przewodniego (s. 223-224).

8 Pojęcie upływu (flux) jest kluczowe dla myśli Caputo (1987); we wskazanej pozycji mowa też o Heideggerowskim pojęciu Abgrund (s. 190, 268). 
Tak powracamy do „horyzontu oczekiwań” jako - po drugie - projekcji historyka. Czy stanowi ona zjawisko nieuniknione? I czy nieuczony, tzw. naiwny odbiorca jego prac nie jest w efekcie obiektem manipulacji? Trzeba tu rozważyć, jaką rolę odgrywają teksty dziejopisów z perspektywy hermeneutycznej. Przecież hermeneutyka (a właściwie również historia) interpretuje nie tyle „nagi” bieg zdarzeń, ile ich świadomościową obróbkę , tzn. dzieje myśli. Ich logika zaś polega ,na konsekwentnej realizacji pewnych sposobów ujmowania rzeczywistości, które sumują się w postaci sieci teorii, będących [...] mapą dziejow[ych] [...] odsłonięć bytu, tj. realizacją jego sensu, a zarazem jego doświadczeniem" (Torzewski, 2012, s. 213). Znowu spotyka się więc porządek egzystencjalny z tekstualnym - tym razem w życiu i pracy historyków. W takim kontekście nawet ich stronnicze wizje można by uznać za świadectwo czasu oraz ważnych dla nich przesłanek, lecz hermeneutyka bynajmniej nie przyzwala im na dowolność, a tym bardziej mistyfikacje. Ricoeur (2008, s. 217) z jednej strony wydaje się zakładać, że aktywność przeszłości niejako sama (?) stopniowo koryguje zniekształcenia; z drugiej akcentuje zobowiązanie historyka, który winien w swoich (re)konstrukcjach oddać sprawiedliwość minionym dziejom, ponieważ reprezentuje wobec nich siebie i czytelników jako nosicieli niespłaconego długu.

\section{Projektowanie sensu}

Rzeczonym długiem byłoby kształtowanie przez dzieje i tradycję naszej przestrzeni doświadczenia, a jednocześnie otwieranie przyszłościowego horyzontu oczekiwań, pomiędzy którymi dokonuje ustawicznego zapośredniczenia projektująca inicjatywa. Jej realizacja z kolei wymaga odsłaniania sensu historii, rozumienia tego, od czego się wychodzi, swego rodzaju warunków początkowych. Tak pojęte projekty snuje młody Szczepański (2009) w 1938 roku, upatrując szansę rozprawy z czasem w twórczości, która czerpałaby z sensów, jakie przebłyskują w przekazach przeszłości i pracach dziejopisów. Jak odnotowuje w dzienniku: „Mówiliśmy [z żoną] o tym,

9 Por. też: „Historyka może nie interesować mentalność sama w sobie, ale znajomość [...] nawyków świadomości, które były właściwe kulturze danej epoki [...] i występowały jako składniki przy tworzeniu [...] zabytku historycznego, tak czy owak w nim się ucieleśniły - jest nieodzownym warunkiem adekwatnego odczytania tkwiącego w nim przesłania" (Guriewicz, 1997, s. 13). 
że chcielibyśmy czytać historię filozofii, geografię i podręczniki historii. [...] Tęskni się po prostu do tych odwiecznych marzeń twórczych, marzeń ludzkich. Mamy potrzebę czytania. Sięgania do ich natchnień poetyckich, żebyśmy i my mogli pisać" (s. 58).

Spowinowacenie dzieł historycznych $\mathrm{z}$ weną i liryzmem zapewne nie oznacza tu romantycznego przeświadczenia o pierwotnym, źródłowym charakterze mowy poetyckiej ani też uwypuklenia metaforyczności owych dzieł. Przywodzi raczej na myśl Arystotelesowskie (1988, 1451b, s. 330) kryterium rozróżnienia historii i poezji; stąd ,,poetyzacja” tej pierwszej zbliża ją do utworów mówiących o tym, co może się wydarzyć. Ponadto „mowa wiązana” odzwierciedla ponadczasowe pragnienie ładu - stanowi projekt nadawania rzeczywistości sensu przez rytm (por. heksametr). Równocześnie Szczepański przypomina znaną prawdę, że pisanie zanurzone jest w już napisanym, czerpie ze zrealizowanych prób odpowiedzi na pytanie przeszłości i samo staje się taką próbą, włącza się w ów polilog. Dotyczy to także innych aktywności twórczych jako inicjatywy, która dzięki wpisaniu w systemy symboliczne może nasycać czas sensem. Jak konkluduje autor Zapytaj samego siebie:

W relacji ,jednostka ludzka - czas” [...] twórczość zmieniająca „czas pusty” na „pełny” gra zasadniczą rolę. Twórczość przekształca neutralną, obojętną rzekę czasu w czynnik niezbędny dla zorganizowania życia $\mathrm{w}$ proces przeciwdziałający niszczącym siłom bytu [...]. Jeszcze ważniejsza jest zdolność człowieka do tworzenia własnego ,,czasu osobistego" [...] [który] wiąże się z czasem wewnętrznym jednostki, co daje zrozumienie jego przebiegu, łączy także czas obiektywny z odczuciem subiektywnym jego natury i doświadczeniami codzienności. [...] Jednostka nie może zmieniać czasu astronomicznego, ale może kształtować i zmieniać treść czasu [...] (Szczepański, 1999, s. 71-72).

Szczepański zapewne podpisałby się pod koncepcją Wilhelma Diltheya, że sednem dziejowości indywiduum jest twórcza energia, dzięki której człowiek buduje świat historyczny, jak również potrafi rozpoznawać siebie w cudzych dziełach, ponieważ każdy stanowi ,moment” tego samego życia (por. Paczkowska-Łagowska, 2000, s. 72). Trzeba jednak dodać, że o ile wspólna przynależność do kreatywnego życia (vel bycia) pozwala do- 
strzec w wytworach innych przejawy pokrewnej potrzeby ekspresji, o tyle z powodu rozmaitości „odgałęzień” owego życia - tj. wielorakich historii - nieraz trudno zrozumieć czy chociażby zaakceptować odmienne tradycje. Cytowany socjolog przywołuje w dzienniku tezę Eduarda Sprangera: „Sens życia jednostki jest określany przez sens obiektywnej kultury historycznej, a kultura historyczna ciągle na nowo jest ożywiana i przekształcana przez żywe dusze, które są jej nosicielami i których nosicielem jest ona" (Szczepański, 2009, s. 80, tłum. własne $)^{10}$. „Kultura historyczna” nazywa tutaj raczej partykularną tradycję i jej przekazy (teksty), ale równocześnie passus ten zdaje się wskazywać na ontologiczny rys egzystencji - omawiane już zanurzenie w dziejach.

Znaczenie świadomego traktowania tego drugiego, szerszego wymiaru dobrze oddaje Marek Szulakiewicz (2011), charakteryzując myśl hermeneutyczną: „Właśnie dlatego, że człowiek jest uwikłany w czas, może rozumieć i mieć nadzieję na prawdę. Proces rozumienia okazuje się sposobem bycia prawdy, to w nim prawda się »wydarza«. [...] I mimo że nikt z nas nie obejmuje całej prawdy, to »cała prawda« obejmuje nas" (s. 128). W owej dialektyce opartej na ludzkiej dziejowości chodzi o coś więcej niż „poznanie samego siebie” przez rozpoznawanie się w dziełach i tekstach przeszłości; mianowicie o przekonanie, że w skończonym istnieniu jednostki nie tyle urzeczywistnia się idea, z której perspektywy przestaje ono być zbyteczne, ile że właśnie $\mathrm{w}$ tym istnieniu rozbłyskuje sens ${ }^{11}$. Nie mamy tutaj do czynienia z polemicznym wobec Marquarda preferowaniem biernego oczekiwania na epifanię sensu ani też ze stanowiskiem, że towarzyszy on człowiekowi samoczynnie i nieprzerwanie. Wspomniana dialektyka jest przecież dialektyką bycia wytworem oraz tworzenia, kultury historycznej oraz jej „,ożywiania i przekształcania”.

${ }^{10}$ Gdzie indziej socjolog deklaruje utopijne stanowisko, wedle którego czas ludzki winno się mierzyć trwaniem życia jednostek oraz ich zobiektywizowanych wytworów: „Z tego punktu widzenia osobnik, który nic nie wniósł do dziedzictwa kulturowego grupy, prawie by nie istniał" (Szczepański, 1995, s. 4).

11 Por. też koncepcje prawdy jako wydarzenia, otwarcia oraz zamieszkiwania, rozwijane przez Vattima (2011, s. 92-98) za Gadamerem i Heideggerem. 


\section{Zakończenie, czyli sploty sensu}

Jak utrzymuje Szczepański, człowiek może postrzegać sens życia jako nadany przez siłę transcendentną albo wypromieniowywać go ze swojej autonomii, indywidualnej mocy twórczej; hermeneutyka zaś dopowiada, że może on być twórczy o tyle, o ile uczestniczy w twórczym, dziejowym wydarzaniu się prawdy. Lecz na czym owo mgliste ,wydarzanie się” konkretnie polega? Nie chodzi wszak o fatalistyczne albo cyniczne powtarzanie implikacji: „jeśli tak się stało, to widocznie tak musiało być”. Najjaśniej i najdobitniej tłumaczy tę rudymentarną ideę Gadamer (1979c): „Prawda historyczna [...] to nie przeświecanie pewnej idei, lecz zobowiązanie narzucone przez niepowtarzalną decyzję" (s. 29). Powracamy więc do kluczowych tu pojęć: jednostkowego wyboru oraz imperatywu świadectwa.

W świetle powyższego za cel (nie w znaczeniu finalizmu, ale indywidualnego zadania) można by uznać roztropne (por. istotną dla Gadamera kategorię phronesis) działanie wywodzące się z namysłu nad dziejami poznawanymi za pośrednictwem tekstów historycznych sensu largo. Namysł ten służyłby rozpoznawaniu wartości, uprzedzeń i nadziei, które świadomie lub mimowiednie wkładali w nie historycy i inni poprzedzający nas interpretatorzy, a w rezultacie - zrozumieniu, w jaki sposób owa zapośredniczona przeszłość wpływa na nasze postępowanie i jakie otwiera dla niego alternatywy. Taka refleksja pozwalałaby na inicjatywę zdolną zwrotnie oddziaływać na sens minionego i na sens tradycji (por. projektowanie historycznego horyzontu), gdyż twórczość w życiu społecznym i kulturze prowadzi do zmiany znaczenia wchłanianych przez współczesność momentów przeszłości.

Zasadne wydaje się wyeksponowanie potencjału zawartego w kole hermeneutycznym, które w tym wypadku można pojmować tak, że jesteśmy dziedzicami przekazów przeszłości (co wiąże się z kategoriami informacji i komunikacji, również w znaczeniu etymologicznym informatio i communitas, czyli z formowaniem oraz wspólnotą). Niemniej dopiero dzięki takiemu rozpoznaniu i ciągłemu rozświetlaniu owego uformowania możemy działać, aby nadawać nowy sens historii. W niniejszym ujęciu nie tylko wytwory dziejopisów, ale też sama dziejowość odsłania swe tekstowe oblicze w nawiązaniu do źródłosłowu tego wyrazu (textura - tkanina, splot):

Dziejowość okazuje się [...] „splotem oddziaływan”. Nie jest on określony jedynie $[\ldots]$ linearnie. Uczestniczymy w nim jako punkt 
przecięcia, w którym spotykają się głosy pochodzące z tradycji oraz nasze własne projekty przyszłości, $[\ldots]$ pragnienia i oczekiwania, nasza postawa teoretyczna i praktyczna, dążenie do indywiduacji z dążeniem do komunikacji (Torzewski, 2012, s. 128).

Należy jeszcze przypomnieć, że wobec tekstów historii nigdy nie stajemy sami, lecz jako członkowie określonych grup czy wspólnot, wraz z którymi je interpretujemy i w ramach których negocjujemy ich znaczenia - co może prowadzić do poszerzania lub przesuwania owych ram.

$$
* * *
$$

Na koniec warto wrócić do kwestii pytań stawianych przeszłości przez człowieka i vice versa, o czym Ricoeur (2008) pisze dalej: „Przeszłość zapytuje nas w tej mierze, w jakiej my ją zapytujemy. Odpowiada nam w tej mierze, w jakiej my jej odpowiadamy" (s. 321-322). Można stąd wnioskować, że nie tyle ,przemawia” ona sama z siebie, ile zwraca się z wezwaniem, odbijając nasze rozterki niczym lustro. Owo pytanie, które ludzie zadają przeszłości, w ostatecznym rozrachunku brzmi najczęściej: „Po co tutaj jestem?”. Przeniesienie akcentu z ,po co” na ,jestem” charakteryzowałoby epikurejską postawę carpe diem, natomiast położenie go na „tutaj”- postawę hermeneutyczną, która koreluje ze stanowiskiem Marquarda, porzucającego pytanie o absolutny sens na rzecz badania, jak codzienne sensy naszego życia wytyczane są przez czas i miejsce, w których się znajdujemy.

Z kolei treść ,pytania przeszłości” podpowiada Szczepański, gdy roztrząsa, dlaczego potocznie mówimy, że rozumiemy czas lub dobrze go wykorzystaliśmy, skoro nie potrafimy go uchwycić (nawet pojęciowo) ani bezspornie zdefiniować. Zauważa, że zwykle naukowcy, myśliciele itp. deliberują nad rolą czasu w życiu abstrakcyjnego Człowieka i wtedy rola ta wydaje się identyczna. Dlatego właśnie - choćby ryzykując niechęć rozmówców - powinniśmy dopytywać innych, czym dla każdego z nich jest czas (por. Szczepański, 1996, s. 12). Byłoby to poniekąd echo metody Sokratesa, który wszak przyrównywał się do gza niepozwalającego ateńczykom na zgnuśnienie $\mathrm{i}$ inercyjne tkwienie $\mathrm{w}$ nurcie czasu. Taką pracę wykonuje też pytanie zadawane przez przeszłość, które stanowi zwierciadlane odbicie pytania człowieka i które może stać się bodźcem do porzucenia spetryfi- 
kowanego modusu bycia-w-świecie ${ }^{12}$. A brzmi ono po prostu: „Co zrobisz z tym, że tutaj jesteś?"

\section{Bibliografia:}

Arystoteles (1988), Poetyka, [w:] tegoż, Retoryka; Poetyka, wstęp i komentarz H. Podbielski. Warszawa: PWN.

Bauman Z. (2009), Konsumowanie życia, thum. M. Wyrwas-Wiśniewska. Kraków: Wydawnictwo Uniwersytetu Jagiellońskiego.

Brach-Czaina J. (1999), Szczeliny istnienia, Kraków: eFKa.

Budrewicz Z., Sendyka R., Nycz R. (red.), (2014). Pamięć i afekty, Warszawa: Wydawnictwo IBL PAN.

Burszta W.J., Kuligowski W. (2005), Sequel. Dalsze przygody kultury w globalnym świecie, Warszawa: Muza.

Caputo J.D. (1987), Radical Hermeneutics. Repetition, Deconstruction and the Hermeneutic Project, Indianapolis: Indiana University Press.

Caputo J.D. (2000), More Radical Hermeneutics. On Not Knowing Who We Are, Indianapolis: Indiana University Press.

Domańska E. (2010), Wokót ,, Metahistorii” [w:] H. White, Poetyka pisarstwa historycznego, red. E. Domańska, M. Wilczyński. Kraków: Universitas, s. 7-30.

Domańska E. (2012), Historia egzystencjalna. Krytyczne studium narratywizmu i humanistyki zaangażowanej, Warszawa: Wydawnictwo Naukowe PWN.

Dybel P. (2012), Oblicza hermeneutyki, Kraków: Universitas.

Feliksiak E. (2014), Przestrzeń antropologiczna jako domena etosu, [w:] tejże, Antropologia literatury. Interpretacje i studia. Kraków: Universitas, s. 15-35.

Gadamer H.-G. (1979a), Cóż to jest prawda?, tłum. M. Łukasiewicz. [w:] tegoż, Rozum, słowo, dzieje. Szkice wybrane, wybór i wstęp K. Michalski. Warszawa: PIW, s. 32-46.

Gadamer H.-G. (1979b), Człowiek i język, tłum. K. Michalski. [w:] tegoż, Rozum, stowo, dzieje. Szkice wybrane, wybór i wstęp K. Michalski. Warszawa: PIW, s. $47-56$.

12 Por.: „Dostrzegać pytania to znaczy uczynić wyłom w zwartym murze presupozycji, który dominuje nad naszym myśleniem i poznawaniem” (Gadamer, 1979a, s. 42). 
Gadamer H.-G. (1979c), Problem dziejów w nowszej filozofii niemieckiej, tłum. K. Michalski. [w:] tegoż, Rozum, słowo, dzieje. Szkice wybrane, wybór i wstęp K. Michalski. Warszawa: PIW, s. 20-31.

Gadamer H.-G. (2003), Tekst i interpretacja, tłum. P. Dehnel. [w:] tegoż, Język i rozumienie, wybór P. Dehnel, B. Sierocka. Warszawa: Fundacja Aletheia, s. 99-141.

Gadamer H.-G. (2007), Prawda i metoda. Zarys hermeneutyki filozoficznej, tłum. i wstęp B. Baran. Warszawa: Wydawnictwo Naukowe PWN.

Guriewicz A. (1997), Historia i antropologia historyczna, tłum. B. Żyłko, „Konteksty. Polska Sztuka Ludowa”, t. 51, nr 1/2, s. 13-20.

Hartman J. (red.), (2004), Słownik filozofii. Kraków: Zielona Sowa.

Heidegger M. (1994), Bycie i czas, tłum. i przypisy B. Baran. Warszawa: Wydawnictwo Naukowe PWN.

Jauss H.R. (1999), Dzieje sztuki i historia, [w:] tegoż, Historia literatury jako prowokacja, tłum. M. Łukasiewicz. Warszawa: Wydawnictwo IBL, s. 181-217.

Leśniewski N. (1998), O hermeneutyce radykalnej, Poznań: Wydawnictwo Naukowe Instytutu Filozofii UAM.

Löwith K. (2002), Historia powszechna i dzieje zbawienia. Teologiczne przesłanki filozofii dziejów, tłum. J. Marzęcki. Kęty: Antyk.

Marquard O. (1994a), Koniec mocy przeznaczenia, [w:] tegoż, Rozstanie z filozofia pierwszych zasad. Studia filozoficzne, tłum. K. Krzemieniowa, Warszawa: Oficyna Naukowa, s. 68-92.

Marquard O. (1994b), W sprawie dietetyki oczekiwania na sens, [w:] tegoż, Apologia przypadkowości. Studia filozoficzne, thum. K. Krzemieniowa. Warszawa: Oficyna Naukowa, s. 31-53.

Marquard O. (2001), Opóźniona moralistyka. Uwagi o nieodzowności humanistyki, [w:] tegoż, Szczęście w nieszczęściu. Rozważania filozoficzne, tłum. K. Krzemieniowa. Warszawa: Oficyna Naukowa, s. 108-115.

Montrose L. (1996), Badania nad renesansem. Poetyka i polityka kultury, tłum. M.P. Markowski. [w:] Współczesna teoria badań literackich za granica. Antologia, t. 4, cz. 2, H. Markiewicz (red.), Kraków: Wydawnictwo Literackie, s. $116-147$.

Nietzsche F. (1908), Ludzkie, arcyludzkie, t. 1, thum. K. Drzewiecki. Warszawa: Oficyna Jakub Mortkowicza. 
Nietzsche F. (1993), O prawdzie i ktamstwie w pozamoralnym sensie [w:] tegoż, Pisma pozostałe 1862-1875 thum. B. Baran. Kraków: Inter-Esse, s. 181-199.

Olsen B. (2013), W obronie rzeczy. Archeologia i ontologia przedmiotów, thum. B. Shallcross. Warszawa: Wydawnictwo IBL PAN.

Paczkowska-Łagowska E. (2000), Logos życia. Filozofia hermeneutyczna w kręgu Wilhelma Diltheya, Gdańsk: Słowo/Obraz Terytoria.

Ricoeur P., (1989), Przyswojenie, [w:] tegoż, Język, tekst, interpretacja. Wybór pism, wybór i wstęp K. Rosner, thum. P. Graff, K. Rosner. Warszawa: PIW, s. 272-289.

Ricoeur P., (2008), Czas i opowieśćć, t. 3: Czas opowiadany, thum. U. Zbrzeźniak. Kraków: Wydawnictwo Uniwersytetu Jagiellońskiego.

Rorty R. (red.), (1967), The Linguistic Turn. Recent Essays in Philosophical Method, Chicago-London.

Szczepański J. (1973), Przykład Jana Wantuły, [w:] tegoż, Odmiany czasu teraźniejszego. Warszawa: Książka i Wiedza, s. 218-225.

Szczepański J. (1990), Historia mistrzynia życia?, Warszawa: Nasza Księgarnia.

Szczepański J. (1995), Czas i kultura, „Przegląd Humanistyczny”, nr 5, s. 1-6.

Szczepański J. (1996), Czas, „Regiony”, nr 4, s. 12-13.

Szczepański J. (1999), Fantazje na temat czasu, Lublin: TN KUL.

Szczepański J. (2009), Dzienniki z lat 1935-1945, red. D. Kadłubiec. Ustroń: Galeria na Gojach.

Szulakiewicz M. (2011), Czas i to, co ludzkie. Szkice z chronozofii i kultury, Toruń: Wydawnictwo Naukowe UMK.

Torzewski W. (2012), Hermeneutyka jako filozofia dziejowości. Studium myśli Diltheya, Yorcka, Heideggera, Gadamera i Vattima, Bydgoszcz: Wydawnictwo Uniwersytetu Kazimierza Wielkiego.

Vattimo G. (1998), Postnowoczesność i kres historii. Tłum. B. Stelmaszczyk. [w:] Postmodernizm. Antologia przekładów, R. Nycz (red.), Kraków: Baran i Suszczyński, s. 128-144.

Vattimo G. (2011), Prawda hermeneutyki. [w:] tegoż, Poza interpretacją. Znaczenie hermeneutyki dla filozofii, Tłum. K. Kasia. Kraków: Universitas, s. 91-111. 


\title{
THE HUMAN IN THE EMPIRE OF TIME, THE SENSE IN THE EMPIRE OF SIGNS. HERMENEUTICS AND THE SENSE OF HISTORY
}

\begin{abstract}
Summary
The linguistic turn has emphasized the linguistic aspect of history as a kind of a tale, unveiling its ideological foundations and rhetorical structure. This article's aim is, however, to prove how seeing history as a collection of texts enables us to regain its subjective sense. The authoress considers the fears of historians' manipulations as well as the validity of »the sense of history «'s question and shows that hermeneutics restores that validity in the epoch after metanarratives' defeat. Referring to Ricoeur, Gadamer, Marquard, Vattimo and also a sociologist Jan Szczepański, this paper displays that we could be perceived as a product of history, but the interpretation of historical texts, sources and traditions, deepens our "being-in-the-world". History appears to be the dialectics of being a product and creating, it relies on decision and obligation. Having understood, how the past mediated by texts - historical interpretations - influences our conduct, we could give it new senses.
\end{abstract}

